\title{
Carta da Editora
}

Estimados leitores e leitoras,

A Revista de Educação Pública conclui o fechamento de mais um quadrimestre, brindando o lançamento de seu último editorial do ano de 2019. Nesserumo, primeiro que tudo, é preciso ressaltar o substancial e volumoso trabalho desempenhado pelos editores e colaboradores que comprometem-se, de forma ativa e responsável, com a comunidade científica, para ampliação das discussóes no campo da Educação. Os diversos assuntos aqui tratados nos 11 artigos, sob enfoques variados, convidam o leitor a trilhar novas experiências, entrelaçadas por conceituados pesquisadores brasileiros e estrangeiros. Não por acaso, iniciamos esta edição do nosso periódico, reafirmando sua internacionalização, com o artigo de pesquisadores vinculados à Universidade de Sherbrooke, Canadá L'effet-tuteur dans l'accompagnement des élèves présentant un trouble neurodéveloppemental, em que realizou-se investigação exploratória sobre a supervisão de alunos com perturbaçôes do desenvolvimento neurológico. Combinando a revisão do trabalho científico com entrevistas semidirecionadas (aluno, pai, mãe, professor), destaca as vantagens do tutor, considerado como uma força no apoio aos alunos. $\mathrm{O}$ sucesso desses alunos requer condiçóes a serem incluídas no currículo, condiçôes que são rápidas para facilitar a melhoria das competências académicas e de desenvolvimento de cada aluno.

No artigo Princípios partilhados nas mudanças empreendidas no Ensino Médio em São Paulo e Mato Grosso, analisa-se a verossimilhança ideológica entre os projetos de reconfiguraçáo do Ensino Médio nos estados de São Paulo e Mato Grosso, em funçáo do processo de instituição da jornada expandida nesses estados. Pensar o projeto de vida do jovem é a centralidade da reestruturaçáo das escolas de Ensino Médio nos modelos investigados, mesmo que ambos os estados considerem as mudanças pelas quais a sociedade passa e a necessidade do contexto escolar estar articulado ao novo perfil de jovem.

Os cantos estão arrumados. E agora, professora? O faz de conta com crianças da educação infantil busca conhecer o que as professoras sabem e como organizam as situaçóes de faz de conta com alunos de educaçáo infantil. Participar da pesquisa possibilitou às professoras refletirem sobre como essas situaçóes de faz de conta são proporcionadas na escola e igualmente, reafirmou o quanto a responsabilidade dos profissionais da educação infantil é imensa. Na sequência, o artigo Os espaços do brincar em uma escola sem brinquedos: o que nos falam as crianças? Ao abordar a análise do ponto de vista das crianças de 6 anos, traz uma contribuição valiosa para pensar um conceito na compreensão de suas vivências: sítios geográficos brincantes, um dos destaques dos achados dessa pesquisa. 
O financiamento da educação na produção acadêmica de programas de pósgraduação no Brasil (2000-2010), visando constituir um panorama da produçáo e localizar as contribuiçóes teóricas que têm maior presença na constituição desse campo de pesquisa, identifica um grupo de pesquisadores de financiamento da educação como principal referencial teórico nas teses e dissertaçóes sobre o tema.

Focalizando Indicadores educacionais do território do Piemonte da DiamantinaBahia: apontamentos iniciais, por meio de uma pesquisa documental na base de dados do INEP, articulando métodos quantitativos e qualitativos de forma inteligível, em meio à complexidade dos fenômenos identificados, o artigo tem o intuito de contribuir para a elaboração e acompanhamento das políticas públicas educacionais voltadas para à melhoria da qualidade da educação.

Devaneio em chamas: Bachelard póe a mão no fogo pelo imaginário, ancorandose na fenomenologia de Gaston Bachelard para definir conceitualmente o imaginário do autor a respeito do fogo, o texto traz uma pesquisa envolvendo estudantes, professoras(es) e moradoras(es) do quilombo Mata Cavalo, zona rural de Nossa Senhora do Livramento-MT, a identificarem os elementos do imaginário quilombola sobre o fogo.

Chamando a atenção para Construçôes discursivas acerca da criança pobre na imprensa uberabense nas primeiras décadas do século $X X$, o artigo investiga as práticas caritativas e filantrópicas de assistência às crianças pobres de Uberaba (MG), com foco nas instituiçóes de internação existentes entre os anos de $1920 \mathrm{a}$ 1964, com destaque para o Orfanato Santo Eduardo.

$\mathrm{O}$ artigo Arquitetura e espaços da cultura escolar: o Ginásio Estadual de Santo Antônio da Platina- PR (1953), tomando como base a historiografia da educação, analisa a solução arquitetônica e a distribuição dos espaços interno do edifício do Ginásio inaugurado em 1953, constituindo-se como lugares de aprendizagens, relaçóes de poder e sociabilidades na cultura escolar secundarista vivida em meados do século XX.

Em A colaboração entre professoras como prática de formação para ensinar matemática nos anos iniciais, a partir de narrativas produzidas pela professora Maria, de relatórios e transcriçóes dos encontros do grupo OBEDUC, evidenciadas pelos indícios de aprendizagem, destacam os processos de apropriaçáo dos modos de aprender e ensinar matemática nos anos iniciais.

As reflexóes contidas em Correlação entre equilibrio emocional e vulnerabilidade às IST/AIDS num estudo sobre desempenho escolar com adolescentes, ao abordarem possíveis relaçóes entre vulnerabilidade às IST/AIDS e indicadores de qualidade de vida para estudantes do ensino médio, identificaram uma significativa correlação entre a qualidade de vida psicológica e a vulnerabilidade. $\mathrm{O}$ recorte envolveu 103 alunos do $3^{\circ}$ ano do ensino médio de três escolas da rede estadual de educação de Aracaju-SE. 
Agregando-se a esta edição, a resenha Comunicação, Estado e o poder na sociedade em rede, nos convida à leitura instigante quanto ao papel das redes de comunicação na geração de poder, com ênfase na geração do poder político.

Esperamos que o conjunto dos textos, ora apresentados, possa provocar diálogos que indagam o já conhecido e nos potencialize a ressignificar e, sobretudo, a esperançar em tempos tão delicados como os que temos vivido em nossas universidades públicas.

Filomena Maria de Arruda Monteiro Editora da Revista de Educação Pública/UFMT 